PART II. PHYSICAL ACTIVITY OF SOCIAL AND PROFESSIONAL GROUPS DZIAŁ II. AKTYWNOŚĆ FIZYCZNA GRUP SPOŁECZNYCH I ZAWODOWYCH

\title{
ECONOMIC CORRELATES OF PHYSICAL ACTIVITY IN ADULTS
}

\section{EKONOMICZNE KORELATY AKTYWNOŚCI FIZYCZNEJ OSÓB DOROSŁYCH}

\author{
Daniel Jan Puciato ${ }^{1(\mathrm{~A}, \mathrm{~B}, \mathrm{D}, \mathrm{E})}$, Michał Rozpara ${ }^{2(\mathrm{C}, \mathrm{D}, \mathrm{E})}$, Władysław Mynarski $^{2(\mathrm{D}, \mathrm{E})}$, \\ Piotr Oleśniewicz ${ }^{3(\mathrm{E}, \mathrm{F})}$, Julita Markiewicz-Patkowska ${ }^{4(\mathrm{E}, \mathrm{G})}$
}

${ }^{1}$ Faculty of Physical Education and Physiotherapy, Opole University of Technology, Poland ${ }^{2}$ Faculty of Physical Education, The Jerzy Kukuczka Academy of Physical Education in Katowice, Poland

${ }^{3}$ Faculty of Physical Education, University School of Physical Education in Wrocław, Poland ${ }^{4}$ Faculty of Finance and Management, WSB University in Wrocław, Poland

Authors' contribution Wkład autorów: A. Study design/planning zaplanowanie badań B. Data collection/entry zebranie danych C. Data analysis/statistics dane - analiza i statystyki D. Data interpretation interpretacja danych E. Preparation of manuscript przygotowanie artykułu F. Literature analysis/search wyszukiwanie i analiza literatury G. Funds collection zebranie funduszy
Tables: 2

Figures: 1

References: 31

Submitted: 2018 Sep 25

Accepted: 2019 Jan 23

\section{Summary}

Background. Physical activity plays an immensely significant role in the prevention and treatment of diseases that often lead to premature death. The aim of this study was to examine the relationships between physical activity of adults and determinants of their financial situation such as steady income, per capita income, savings, and indebtedness.

Material and methods. The study was carried out between 2014 and 2015 in Wrocław, Poland on a group of 4332 residents aged 18 to 64 years. The respondents' habitual physical activity levels and income status were assessed with the International Physical Activity Questionnaire Short Form (IPAQ-SF) and the author's own Socio-Economic Status of Working Age People Questionnaire (S-ESQ), respectively.

Results. There are positive correlations between physical activity level and socio-economic status. Steady income and per capita income are two determinants of differences in physical activity in individuals over 44 years of age. The highest level of physical activity was noted in adults with a steady income of more than USD 542 per month. Respondents with savings were also more physically active than their counterparts without savings. Finally, Wrocław residents who were without debts and who were aged 18-44 years were more physically active than were financially indebted residents.

Conclusions. Actions should be undertaken to enhance physical activity of those adults remaining in a poor socio-economic situation.

Keywords: adults, physical activity, income status

\section{Streszczenie}

Wprowadzenie. Aktywność fizyczna odgrywa istotną rolę w profilaktyce i terapii chorób, które są często przyczyną przedwczesnych zgonów. Celem pracy jest identyfikacja związków zachodzących między poziomem aktywności fizycznej a takimi aspektami sytuacji materialnej, jak: występowanie stałego źródła dochodów, wysokość dochodów na osobę oraz posiadanie oszczędności i zadłużenia u osób dorosłych.

Materiał i metody. Badania przeprowadzono w 2014 i 2015 roku we Wrocławiu (Polska). Materiał badań liczył 4332 osoby w wieku od 18 do 64 lat. Poziom nawykowej aktywności fizycznej i sytuację materialną badanych oceniono za pomocą Międzynarodowego Kwestionariusza Aktywności Fizycznej w wersji krótkiej oraz Kwestionariusza Statusu Społeczno-Ekonomicznego Osób Dorosłych.

Wyniki. Występują dodatnie korelacje między poziomem aktywności fizycznej a statusem społeczno-ekonomicznym. Stały dochód oraz jego wysokość na osobę to czynniki różnicujące aktywność fizyczną badanych w wieku powyżej 44 lat. Najwyższym poziomem aktywności fizycznej cechowały się osoby o stałych dochodach w wysokości powyżej 542 dolarów miesięcznie. Badani posiadajacy oszczędności cechowali się wyższym poziomem aktywności fizycznej od osób ich nieposiadających. Niezadłużeni wrocławianie w wieku od 18 do 44 lat byli bardziej aktywni fizycznie od osób posiadających długi.

Wnioski. Należy podjąć działania zmierzające do zwiększenia aktywności fizycznej osób znajdujących się w niekorzystnej sytuacji materialnej.

Słowa kluczowe: osoby dorosłe, aktywność fizyczna, czynniki ekonomiczne

Puciato DJ, Rozpara M, Mynarski W, Oleśniewicz P, Markiewicz-Patkowska J. Economic correlates of physical activity in adults. Health Prob Civil. 2019; 13(2): 129-134. https://doi.org/10.5114/hpc.2019.83301

Address for correspondence / Adres korespondencyjny: Daniel Jan Puciato, Faculty of Physical Education and Physiotherapy, Opole University of Technology, Prószkowska 76, 45-758 Opole, Poland, e-mail: d.puciato@po.opole.pl, phone: +48 7744980 00;

ORCID: Daniel Jan Puciato https://orcid.org/0000-0002-2390-6038, Michał Rozpara https://orcid.org/0000-0003-3571-6677,

Władysław Mynarski https://orcid.org/0000-0003-4940-6231, Piotr Oleśniewicz https://orcid.org/0000-0002-0426-0630,

Julita Markiewicz-Patkowska https://orcid.org/0000-0003-4408-5387

Copyright: (C) Pope John Paul II State School of Higher Education in Biała Podlaska, Daniel Jan Puciato, Michał Rozpara, Władysław Mynarski, Piotr Oleśniewicz, Julita Markiewicz-Patkowska. This is an Open Access journal, all articles are distributed under the terms of the Creative Commons Attribution-NonCommercialShareAlike 4.0 International (CC BY-NC-SA 4.0) License (http://creativecommons.org/licenses/by-nc-sa/4.0/), allowing third parties to copy and redistribute the material in any medium or format and to remix, transform, and build upon the material, provided the original work is properly cited and states its license. 


\section{Introduction}

Several studies have confirmed the significant role of physical activity in the prevention and treatment of diseases that often lead to premature death $[1,2,3]$. Positive correlations between physical activity and physical performance and fitness have also been proven [4]. Undertaking physical activity of the proper frequency, volume, and intensity has beneficial effects on both the mental health [5] and overall quality of life of adults [6, 7,8].

According to Sallis et al. [9], physical activity can by determined by a number of factors, including one's socioeconomic status. Chung et al. [10], Kim and So [11], and Biernat [12] have noted that people with higher incomes are more physically active than those with lower incomes. Research carried out on groups of manual workers in Brazil [13] and China [14] revealed the highest physical activity levels among people with the highest and the lowest incomes. On the other hand, Van Stralen [15] found that economic status was not significantly correlated with the amount of physical activity undertaken.

Earlier studies have in fact reached divergent conclusions. Moreover, the socio-economic status of study participants has been investigated only in relation to income per capita, without considering other significant determinants of income status such as steady income, money savings, or indebtedness. The aim of the present study was to examine relationships between physical activity levels and such determinants of financial situation as steady income, per capita income, savings, and indebtedness in adult residents of the city of Wrocław, Poland.

\section{Material and methods}

This study took place between 2014 and 2015 in Wrocław, Poland. The research project was approved by the Commission of Bioethics of the University of Physical Education in Wrocław. The research sample consisted of 4332 people aged 18-64 years. The sample selection was random, using a three-level stratification. The division of respondents into age groups was based on the classification of the Polish Central Statistical Office of working age into the so-called mobile age (18-44 years) and immobile age (45-65 years). The respondents' income category was defined in consideration of the social minimum level and average gross income per capita in a oneperson household. Almost $81 \%$ of the studied residents had a steady income. For $45 \%$, the average monthly income per capita was from USD 271 to 542; for 28\% - below USD 271; and for 27\% - above USD 542. About 46\% of respondents had money savings, and $49 \%$ were in debt. Statistically significant differences in income status variables were found between subjects aged over and under 44 years (Table 1).

Table 1. The number and percentage of participants in groups according to their age and selected variables of income status

\begin{tabular}{|c|c|c|c|c|c|c|c|c|c|}
\hline \multirow[t]{2}{*}{ Variable } & \multirow[t]{2}{*}{ Category } & \multicolumn{2}{|c|}{$\begin{array}{c}\text { total } \\
n=4332\end{array}$} & \multicolumn{2}{|c|}{$\begin{array}{c}\text { under } 44 \text { years } \\
n=2593\end{array}$} & \multicolumn{2}{|c|}{$\begin{array}{c}\text { over } 44 \text { years } \\
n=1739\end{array}$} & \multirow[t]{2}{*}{$\chi^{2}$} & \multirow{2}{*}{$\mathbf{p}$} \\
\hline & & $\mathrm{n}$ & $\%$ & $\mathbf{n}$ & $\%$ & $\mathbf{n}$ & $\%$ & & \\
\hline \multirow{2}{*}{ Steady income } & Yes & 3494 & 80.7 & 2017 & 77.8 & 1477 & 84.9 & \multirow{2}{*}{34.08} & \multirow{2}{*}{$<0.001$} \\
\hline & No & 838 & 19.3 & 576 & 22.2 & 262 & 15.1 & & \\
\hline \multirow{3}{*}{ Per capita income } & below USD 271 & 1214 & 28.0 & 746 & 28.8 & 468 & 26.9 & \multirow{3}{*}{2.12} & \multirow{3}{*}{$\geq 0.05$} \\
\hline & USD 271-542 & 1957 & 45.2 & 1167 & 45.0 & 790 & 45.4 & & \\
\hline & above USD 542 & 1161 & 26.8 & 680 & 26.2 & 481 & 27.7 & & \\
\hline \multirow{2}{*}{ Savings } & Yes & 2009 & 46.4 & 1210 & 46.7 & 799 & 45.9 & \multirow{2}{*}{0.22} & \multirow{2}{*}{$\geq 0.05$} \\
\hline & No & 2323 & 53.6 & 1383 & 53.3 & 940 & 54.1 & & \\
\hline \multirow{2}{*}{ Indebtedness } & Yes & 2107 & 48.6 & 1127 & 43.5 & 980 & 56.4 & \multirow{2}{*}{69.24} & \multirow{2}{*}{$<0.001$} \\
\hline & No & 2225 & 51.4 & 1466 & 56.5 & 759 & 43.6 & & \\
\hline
\end{tabular}

Notes: $\chi^{2}$ - chi-squared independence test, $p$ - chi-squared independence test probability value

The study used an auditorium survey. Respondents' habitual physical activity and income status were assessed with the use of the International Physical Activity Questionnaire Short Form (IPAQ-SF) [16] and the author's own Socio-Economic Status of Working Age People Questionnaire (S-ESQ).

The data from IPAQ-SF were used to determine respondents' energy expenditure on physical activity (EEPA) expressed in MET-min/week, calculated following the Guidelines for Data Processing and Analysis of the International Physical Activity Questionnaire as a total of physical activities at three intensity levels performed by respondents on a weekly basis [16].

The S-ESQ was used to determine four income status variables: steady income (YES, NO), per capita income in a household (< USD 271, USD 271-542, > USD 543), having savings (YES, NO), and indebtedness (YES, NO). 
For each independent variable, the size (n) and ratios (\%) for the age groups and the whole study group were estimated. Differences in the financial status of Wrocław residents in regard to their age were verified with Pearson's chi-squared test of independence $\left(\chi^{2}\right)$. As for the EEPA (dependent variable), arithmetic means were calculated for the total group, age groups, and groups according to particular variables of income status. Relationships between residents' physical activity levels and income status were verified with the one-factor ANOVA test (F), and multiple regression analysis, separately for residents over and under 44 years. The levels of statistical significance were set at $\alpha<0.05$ and $\alpha<0.001$. All statistical calculations were made with the use of Statistica 13.1 (Dell Inc.).

\section{Results}

The analysis of mean values of the EEPA index in groups according to the variable of having a steady income revealed significant differences between individuals with and without a steady income in the group above 44 years of age $(F=36.1, p<0.001)$. The mean EEPA in individuals with a steady income amounted to 2841 MET-min/week, and in individuals without a steady income - to 1768 MET-min/week. Among the Wrocław residents aged above 44 years, the mean EEPA values differed significantly between groups according to income per capita $(\mathrm{F}=10.4, \mathrm{p}<0.001)$. The highest level of physical activity (3197 MET-min/week) was found among residents with income over USD 542 per month, and the lowest (2267 MET-min/week) among residents with income below USD 271. Also the highest EEPA was found in residents under 44 years of age (3074 MET-min/ week) and over 44 years of age (2972 MET-min/week) who had money savings. The levels of physical activity among these residents were significantly higher $(\mathrm{p}<0.001$ - residents under 44 years of age; $p<0.05$ - residents over 44 years of age) than levels in residents without money savings (2485 MET-min/week in residents under 44 years of age; 2431 MET-min/week in residents over 44 years of age). The F-distribution value $(\mathrm{F}=41.8)$ and $\mathrm{p}<$ 0.001 showed that physical activity levels were also significantly different among indebted respondents under 44 years. The mean EEPA (3011 MET-min/week) of residents with no debt was higher than for residents with debt (2433 MET-min/week) (Figure 1).

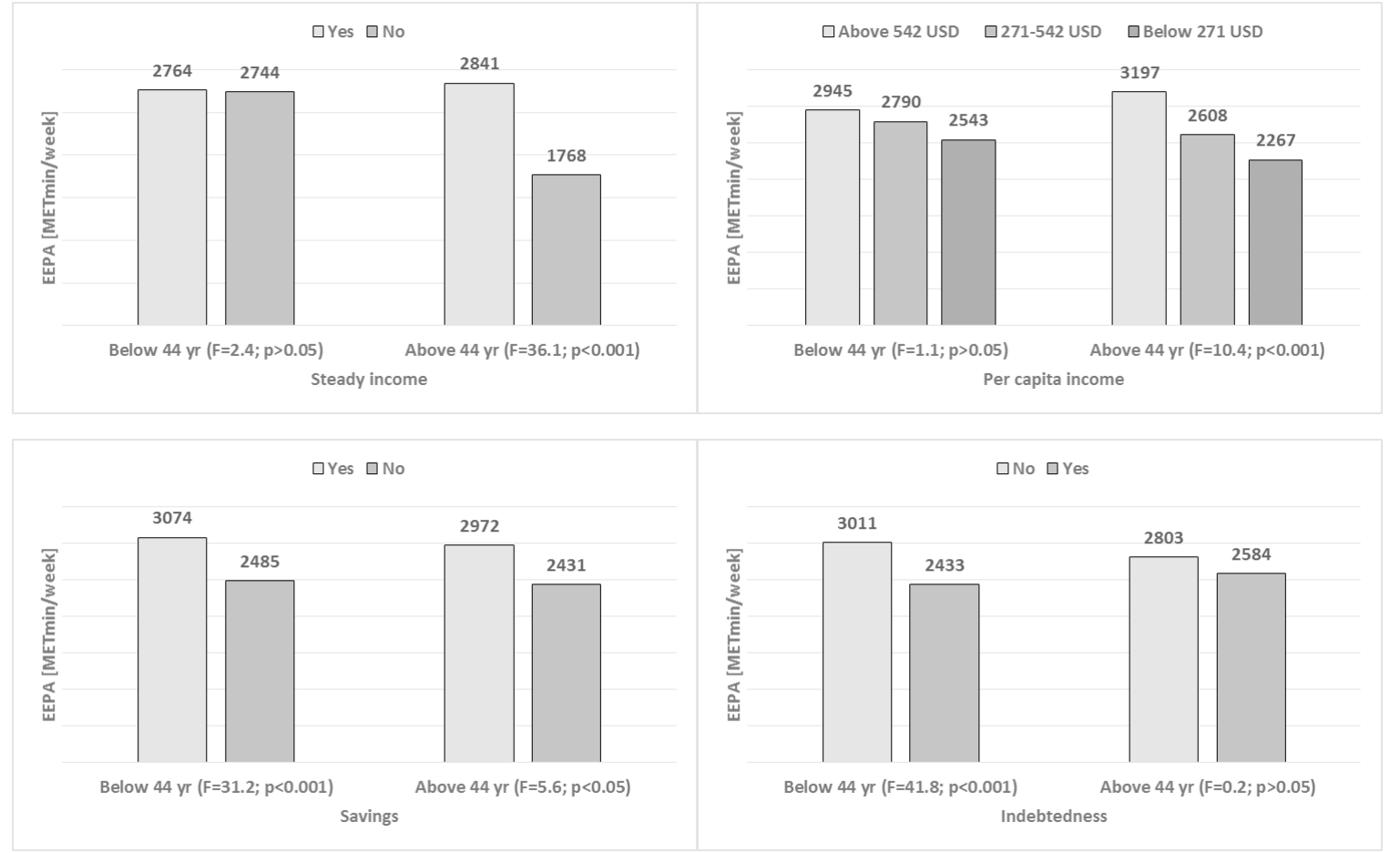

Figure 1. Differences in physical activity levels in groups of respondents according to age and income status variables

Table 2 shows multiple regression models illustrating relationships between EEPA (dependent variable) and the income status of adult Wrocław residents (independent variables). Significant correlations were found between physical activity levels, money savings, and indebtedness ( $p<0.001)$ among residents under 44 years of age. The level of total physical activity was the highest in individuals with money savings and without indebtedness (Table 2). 
Table 2. Respondents' physical activity levels and income status variables

\begin{tabular}{|c|c|c|c|c|c|c|c|c|c|}
\hline \multirow{2}{*}{ Variable } & \multirow{2}{*}{ Category } & \multicolumn{4}{|c|}{ under 44 years } & \multicolumn{4}{c|}{ over 44 years } \\
\cline { 3 - 9 } & & $\boldsymbol{\beta}$ & $\mathbf{S E}$ & $\mathbf{t}$ & $\mathbf{p}$ & $\boldsymbol{\beta}$ & $\mathbf{S E}$ & $\mathbf{t}$ & $\mathbf{p}$ \\
\hline & Intercept & 2786.4 & 44.9 & 62.05 & $<0.001$ & 2425.1 & 67.7 & 35.82 & $<0.001$ \\
\hline Steady income $^{\text {a }}$ & Yes & -69.8 & 44.6 & -1.56 & $\geq 0.05$ & 409.3 & 68.1 & 6.01 & $<0.001$ \\
\hline \multirow{2}{*}{ Per capita income $^{\mathrm{b}} \mathrm{b}$} & below USD 271-542 & -9.8 & 48.1 & -0.20 & $\geq 0.05$ & -116.3 & 61.7 & -1.89 & $\geq 0.05$ \\
\cline { 2 - 10 } & above USD 542 & 86.4 & 59.1 & 1.46 & $\geq 0.05$ & 337.6 & 74.0 & 4.56 & $<0.001$ \\
\hline Savings $^{\mathrm{c}}$ & Yes & 229.1 & 41.0 & 5.59 & $<0.001$ & 120.0 & 50.5 & 2.38 & $<0.05$ \\
\hline Indebtedness $^{\text {d }}$ & No & 239.2 & 37.0 & 6.47 & $<0.001$ & 23.0 & 47.5 & 0.48 & $\geq 0.05$ \\
\hline
\end{tabular}

Notes: ${ }^{\mathrm{a}}$ The reference category for having a steady income is $\mathrm{NO},{ }^{\mathrm{b}}$ The reference category for per capita income is below 271 USD, ${ }^{c}$ The reference category for having savings is NO, ${ }^{\mathrm{d}}$ The reference category for indebtedness is YES

Abbreviations: $\boldsymbol{\beta}$ - assessment value of model parameters, SE -standard error $\boldsymbol{\beta}, \mathrm{t}$ - parameter significance, $p$ - probability value

In the group of residents over 44 years of age, statistically significant correlations were found between physical activity and having a steady income $(\mathrm{p}<0.001)$, having a monthly income per capita of above USD $542(\mathrm{p}<0.001)$, and having savings $(\mathrm{p}<0.05)$. Respondents with a steady income were more physically active than those without one, and respondents with the highest per capita income were more physically active that respondents with medium and low per capita income. Among the Wrocław residents above 44 years of age, having savings was correlated with a higher level of physical activity (Table 2).

\section{Discussion}

This study reveals positive correlations between physical activity levels and income status of adult residents of Wrocław. Steady income and per capita income are significant differentiating factors of physical activity of respondents aged over 44 years. The highest physical activity levels were found in individuals with a steady income above USD 542 per month. Wrocław residents with money savings, regardless of their age, were more physically active than their counterparts without savings. In the group of Wrocław residents under 44 years of age, respondents with debts reported a lower level of physical activity than did their debt-free counterparts.

Having a steady income has not been previously studied as a determinant of physical activity level. In the present study, such correlations were only found in Wrocław residents over 44 years. Residents with a steady income usually work full time in their profession. Previous researchers have proven a significant contribution of physical activity related to the performance of professional chores and to commuting to total physical activity [17]. Higher physical activity levels have also been found in working individuals than in the unemployed [18].

The level of physical activity of Wrocław residents aged over 44 years in this study also differed significantly in terms of per capita income, especially among individuals with the highest income. Higher physical activity levels along increasing income per capita were also found by Choi et al. [19], Kim and So [11], and Kari et al. [20]; and among a Polish population by Biernat [12], Biernat and Piątkowska [21], Pocztarska and Bergier [22], and Puciato [23]. Correlations between physical activity and the highest income status were investigated by Chung et al. [10]. High incomes allow for purchasing various goods and services directly (e.g. gym subscriptions) or indirectly (e.g. transportation to and from gym facilities). Also, individuals of high-income status have been shown to use their leisure time rationally, i.e. mostly actively, due to it being a limited resource [24].

Interestingly, this study did not reveal significant correlations between steady income and income per capita and physical activity levels in respondents aged 18-44 years. The dynamic socio-cultural transformations that younger generations of Poles especially are so much subjected to have not made steady employment as valuable as it has been for the older generations. People below the age of 44 very often work part-time or occasional jobs, both of which make their activities more flexible. Income level usually increases with age. Additionally, for young people satisfaction from work can also come from pursuing their own interests, self-fulfillment opportunities, and leisure resources [25].

Regardless of Wrocław residents' age, their physical activity level was significantly affected by the fact of having savings. Money savings are complement to one's income and an important co-determinant of household status. The relationships of adults' physical activity with savings is analogous to those with income per capita. Moreover, according to the National Bank of Poland [26], the saving rate at the end of 2015, calculated as gross saving divided by gross disposable income, was only $1.6 \%$. In terms of savings, Poland ranked $39^{\text {th }}$ in the world, and having greater savings was characteristic of not only citizens of the wealthiest countries, but also of countries with a similar level of socio-economic development to Poland, i.e. Portugal, Greece, Hungary, Czech 
Republic, or Bulgaria. It can be thus concluded that in the Polish economic reality having savings remains the preserve of a rather narrow group of wealthy individuals whose levels of physical activity are the highest.

The last variable contributing to the economic situation of Wrocław residents in this study was indebtedness, which significantly affected physical activity differences in respondents under 44 years. At the end of 2015, the financial liabilities of Polish households amounted to USD 170.2 bilion (USD 4428.7 per capita) [26], which meant that about 31.5\% of Poles had debts. For about 33\% of indebted Poles, their debts exceeded their annual household income. Debt payments always erode current income and can contribute to the deterioration of a household's social functioning [27]. They are often associated with the necessity of taking extra jobs, which further constrain leisure time. The most common forms of debt are real estate mortgages, home renovation loans, or consumer durables loans. It must be stressed that in Poland these liabilities are usually incurred by young people at the start of their professional career or family life. This explains why indebtedness was an income status index significantly affecting the level of physical activity in the younger age group under study.

Since the physical activity of adults is highly significant for their proper social and individual functioning [2831], it is necessary to undertake effective actions regarding individuals prone to hypokinesia, i.e. people without a steady income, low income, no money savings, and debt. Programs aimed at improving physical activity levels should be initiated by these individuals as well as companies, local authorities, or government institutions.

\section{Conclusions}

Positive correlations are found between physical activity and the socio-economic status of a working-age population from Wrocław, Poland. The study of physical activity has a number of significant and broad practical implications for public health. It is necessary to seek new and effective remedial programs regarding hypokinesia. The results show that individuals prone to hypokinesia are people with low income, with no money savings, and with debts. More physical activity, and thus, better health status and quality of life, can greatly contribute to higher work efficacy of working-age people and significantly improve the output of business companies and national economies.

\section{References:}

1. Buman M, Hu F, Newman E, Smeaton A, Epstein D. Behavioral periodicity detection from $24 \mathrm{~h}$ wrist accelerometry and associations with cardiometabolic risk and health-related quality of life. Biomed Res Int. 2016; 2016: article ID 4856506. https://doi.org/10.1155/2016/4856506

2. Mynarski W, Psurek A, Borek Z, Rozpara M, Grabara M, Strojek K. Declared and real physical activity in patients with type 2 diabetes mellitus as assessed by the International Physical Activity Questionnaire and Caltrac accelerometer monitor: a potential tool for physical activity assessment in patients with type 2 diabetes mellitus. Diabetes Res Clin Pr. 2012; 98(1): 46-50. https://doi.org/10.1016/j.diabres.2012.05.024

3. Williamson W, Boardman H, Lewandowski A, Leeson P. Time to rethink physical activity advice and blood pressure: a role for occupation-based interventions?. Eur J Prev Cardiol. 2016; 23(10): 1051-1053. https://doi.org/10.1177/2047487316645008

4. Rożek-Piechura K, Ignasiak Z, Sławińska T, Piechura J, Ignasiak T. Respiratory function, physical activity and body composition in adult rural population. Ann Agr Env Med. 2014; 21(2): 369-374. https://doi.org/10.5604/1232-1966.1108607

5. Dziubek W, Kowalska J, Kusztal M, Rogowski Ł, Gołębiowski T, Nikifur M, et al. The level of anxiety and depression in dialysis patients under-taking regular physical exercise training - a preliminary study. Kidney Blood Press R. 2016; 41(1): 86-98. https://doi.org/10.1159/000368548

6. Krzepota J, Biernat E, Florkiewicz B. The relationship between levels of physical activity and quality of life among students of the university of third age. Cent Eur J Publ Heal. 2015; 23(4): 335-339. https://doi.org/10.21101/cejph.a4136

7. Puciato D, Borysiuk Z, Rozpara M. Quality of life and physical activity in an older working-age population. Clin Interv Aging. 2017; 12: 1627-1634. https://doi.org/10.2147/CIA.S144045

8. Puciato D, Rozpara M, Borysiuk Z. Physical activity as a determinant of quality of life in working-age people in Wrocław, Poland. Int J Env Res Pub He. 2018; 15(4): 623. https://doi.org/10.3390/ijerph15040623

9. Sallis J, Cervero R, Ascher W, Henderson K, Kraft M, Kerr J. An ecological approach to creating more physically active communities. Annu Rev Public Health. 2006; 27(1): 297-322, 2006.

https://doi.org/10.1146/annurev.publhealth.27.021405.102100

10. Chung S, Domino M, Stearns S, Popkin B. Retirement and physical activity analyses by occupation and wealth. Am J Prev Med. 2008; 36(5): 422-428. https://doi.org/10.1016/j.amepre.2012.05.026 
11. Kim I, So W. The relationship between household income and physical activity in Korea. J Phys Ther Sci. 2014; 26(12): 1887-1889. https://doi.org/10.1589/jpts.26.1887

12. Biernat E. Factors increasing the risk of inactivity among administrative, technical and manual workers in Warszawa public institutions. Int J Occup Med Env. 2015; 28(2): 283-294. https://doi.org/10.13075/ijomeh.1896.00194

13. Garcez A, Canuto R, Paniz V, Olinto BA, Macagnan J, Henn RL, et al. Association between work shift and the practice of physical activity among workers of a poultry processing plant in Southern Brazil. Nutr Hosp. 2015; 31(5): 2174-2181. https://doi.org/10.3305/nh.2015.31.5.8628

14. Attard S, Howard A, Herring A, Zhang B, Du S, Aiello AE, et al. Differential associations of urbanicity and income with physical activity in adults in urbanizing China: findings from the population-based China Health and Nutrition Survey 1991-2009. Int J Behav Nutr Phy. 2015; 12: 152. https://doi.org/10.1186/s12966-015-0321-2

15. Van Stralen M, De Vries M, Mudde A, Bolman C, Lechner L. Determinants of initiation and maintenance of physical activity among older adults: a literature review. Health Psychol Rev. 2009; 3(2): $147-207$. https://doi.org/10.1080/17437190903229462

16. International Physical Activity Questionnaire [Intenet]. [cited 2014 Oct 17]. Available from: http://ipaq.ki.se/ipaq.htm

17. Kwaśniewska M, Pikala M, Bielecki W, Dziankowska-Zaborszczyk E, Rębowska E, Kozakiewicz K, et al. Tenyear changes in the prevalence and socio-demographic determinants of physical activity among Polish adults aged 20 to 74 years. Results of the National Multicenter Health Surveys WOBASZ (2003-2005) and WOBASZ II (2013-2014). Plos One. 2016; 11(6): e-0156766. https://doi.org/10.1371/journal.pone.0156766

18. Puciato D, Rozpara M, Mynarski W, Łoś A, Królikowska B. Physical activity of adult residents of Katowice and selected determinants of their occupational status and socio-economic characteristics. Med Pr. 2013; 64(5): 649-657. https://doi.org/10.13075/mp.5893.2013.0064

19. Choi B, Schnall P, Yang H, Dobson M, Landsbergis P, Israel L, et al. Psychosocial working conditions and active leisure-time physical activity in middle-aged US workers. Int J Occup Med Env. 2010; 23(3): $239-253$. https://doi.org/10.2478/v10001-010-0029-0

20. Kari J, Pehkonen J, Hirvensalo M, Yang X, Hutri-Kähönen N, Raitakari OT, et al. Income and physical activity among adults. Evidence from self-reported and pedometer-based physical activity measurements. Plos One. 2015; 10(8): e-0135651. https://doi.org/10.1371/journal.pone.0135651

21. Biernat E, Piątkowska M. [Recreational physical activity of Poles compared to other Europeans. Report for Department of Analyses and Sports Policy of Ministry of Sport and Tourism]. Warszawa: Ministerstwo Sportu i Turystyki; 2012 (in Polish).

22. Pocztarska A, Bergier J. Demographic variables versus physical activity level of the Nałęczów Health Resort visitors. Health Prob Civil. 2015; 4(9): 54-60. https://doi.org/10.5114/hpc.2015.57703

23. Puciato D. Physical activity of men from Wroclaw in the view of their discretionary income. J Phys Ther Sci. 2016; 28(9): 2641-2643. https://doi.org/10.1589/jpts.28.2641

24. Puciato D. Leisure as a determinant of life quality exemplified by empirical research. Studies and Works of the College of Management and Finance. 2009; 95: 97-109.

25. Czapiński J, Panek T. Social Diagnosis 2015. Objective and subjective quality of life in Poland. Quarterly of University of Finance and Management in Warsaw. 2015; 9(4): 56-59.

26. Kolasa A, Premik F, Tyrowicz J. The financial situation of the household sector in the fourth quarter of 2015. Warszawa: NBP; 2016.

27. Pucci G, Reis R, Rech C, Hallal P. Quality of life and physical activity among adults: population-based study in Brazilian adults. Qual Life Res. 2012; 21(9): 1537-1543. https://doi.org/10.1007/s11136-011-0083-5

28. Nawrocka A, Garbaciak W, Cholewa J, Mynarski W. The relationship between meeting of recommendations on physical activity for health and perceived work ability among white-collar workers. Eur J Sport Sci. 2018; 18(3): 415-422. https://doi.org/10.1080/17461391.2018.1424257

29. Dubray A, Bergier J, Gładysz I. Role of physical activity in the lifestyle of French nurses. Health Prob Civil. 2017; 11(4): 253-260. https://doi.org/10.5114/hpc.2017.72362

30. Nowak R, Kostrzewa-Nowak D, Jastrzębski Z, Zarębska A, Cięszczyk P. High and low impact aerobic exercise as a method of early prevention of Hypercholesterolaemia development among young women. Hum Mov. 2018; 17(4): 242-249. https://doi.org/10.1515/humo-2016-0030

31. Myrna-Bekas R, Kałwa M, Stefaniak T, Kulmatycki L. Mood changes in individuals who regularly participate in various forms of physical activity. Hum Mov. 2018; 13(2): 170-177. https://doi.org/10.2478/v10038-012-0019-0 